\title{
長繊維強化セラミック基複合材料の強化・高勒化設計
}

\author{
伊藤義康・亀田常治・須山章子・永田晃則 \\ (株)東芝電力産業システム技術開発センター, 230-0045 神奈川県横浜市鶴見区末広町 2-3
}

\section{Material Design for High Strength and Toughness of Continuous Fiber-Reinforced Ceramic Matrix Composites}

\author{
Yoshiyasu ITOH, Tsuneji KAMEDA, Shoko SUYAMA and Kohsoku NAGATA \\ Power \& Industrial Systems Research \& Development Center, Toshiba Co., 2-3, Suehiro-cho, Tsurumi-ku, Yokohama-shi 230-0045
}

\begin{abstract}
Crack growth behaviors in continuous fiber-reinforced ceramic matrix composites have been analyzed in termes of stress intensity factors using the finite-element method. Namely, the effects of Young's modulus ratio, $E_{\mathrm{m}} / E_{\mathrm{f}}$, and fiber volume fraction, $V_{\mathrm{f}}$, on the stress intensity factors have been investigated. As a result, it was confirmed that the stress intensity factor increased with increasing the Young's modulus ratio and decreasing the fiber volume fraction. Also, the results showed that a matrix with a low Young's modulus and a low thermal expansion coefficient is effective for preventing crack growth from the matrix through the fiber.

[Received March 26, 1998; Accepted September 11, 1998]
\end{abstract}

Key-words : Continuous fiber-reinforced ceramic matrix composite, Stress intensity factor, Finite-element method, Crack growth, Young's modulus ratio, Fiber volume fraction

\section{1. 緒言}

21世紀に向けて, 発電効率の向上を目指した高温ガスター ビン・プラントの開発はますます加速される傾向にあり, 耐熱 材料の開発も更にその重要性を増している，最近のセラミック スの開発に関しても，䩗性向上などの急速な進歩が見られると ともに，研究開発の主体がモノリシックセラミックスから，セ ラミック基複合材料 (Ceramic matrix composites: CMC) の 開発に重点が移りつつある1) 3)。これはセラミックス本来の 耐熱性に加えて, 高強度セラミック繊維上の複合化により, 見 掛けの破壊勒性值の向上が望めるからである。セラミック基複 合材料がガスタービン高温部品へ適用された場合には高い信頼 性が確保できると期待されている。

ところで, CMC の材料設計はマトリックスと強化繊維の材 料選択, マトリックスと強化繊維の適合設計, 複合化プロセス の選択から構成される。従来から, 複合材料の織り構造, 織り 形状などの構造設計に関しては比較的多くの研究が行われてき たが，これらの材料設計に関しては必ずしも明確な方法が示さ れているとは言えない。これは CMCの材料設計事象に抢ける 素過程が複雑で全体像が把握しにくいこと,き裂のブリッジン グによる勒性発現効果に多くの興味が集中したことなどのため 上考えられる。これからは CMCの多様な破壊現象を分析し， 分類することにより，材料設計の体系化を推し進める必要があ る(4),5)。著者らは，このような観点から $\mathrm{CMC}$ の最終強度を規 定するセラミック䋐維自体の機械的特性, 特に界面制御用の窒 化ホウ素 (BN) コーティングが強化繊維の引張強度に及ぼす 影響について報告した6).

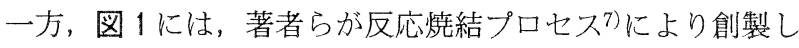
た炭化ケイ素 ( $\mathrm{SiC}$ ) 長繊維強化 $\mathrm{SiC}$ 基複合材料の, 常温に扝 ける引張試験結果の一例を示す。図中に示すように一方向に $30 \mathrm{vol} \%$ の $\mathrm{SiC}$ 長繊維を含有する $\mathrm{SiC}$ 基複合材料が, 強化繊維 方向に引張応力を受ける場合の実験結果である. 負荷応力レベ ルが $170 \mathrm{MPa}$ 以上でマトリックスにき裂が発生し，負荷応力 の増大に伴いマトリックス中のき裂は多発する傾向を示した.

負荷応力レベルが約 $400 \mathrm{MPa}$ に達すると急激にひずみが増大 し, 纎維の引き抜けが顕著となり, $556 \mathrm{MPa}$ で最高荷重点を
示した後に，若干の荷重低下を示して急速破断に至った。この ような破壊過程の中でマトリックス中のき裂発生・進展特性は CMCの許容限界応力を規定する意味から重要であるととも に，強度や勒性発現のための材料設計指針を与えるものと考え られる。

以上より, 本研究ではセラミック基複合材料のマトリックス におけるき裂発生特性に及ぼす緎維含有率, マトリックスと緎 維とのヤング率比の影響について, 破壊力学手法に基づいて解 析的検討を加えることを目的とする。また，得られた結果を基 にマトリックスと強化繊維の材料選択について考察を加える.

\section{2. 解析方法とモデル}

著者らは $\mathrm{CMC}$ 材料設計法の確立を目指し， $\mathrm{CMC}$ のメゾス コピック領域での破壞メカニズムについて注目し，力学的検討 を加えてきた ${ }^{8)}$. 図 2 にはセラミック基複合材料が強化䋐維の 方向に一様引張応力を受ける場合の, 単繊維に注目した破壊過 程をモデル化して示す。マトリックスと強化繊維の材料選択, マトリックスと強化繊維の適合設計においては，このような一 方向単繊維モデルの設定が材料設計のための一般的な考え方を 明らかにするためには有効である8, 9)。図 1 からセラミック基 複合材料の破壊は, マトリックスのき裂発生・進展過程, マト リックス/繊維界面のはく離による引き抜け過程, 強化䋐維自 体の破壊過程の3 ステップから構成される。本研究では, マ トリックスのき裂発生・進展過程, 特にき裂発生に注目して解 析的検討を加える10) 12).

本研究では応力解析モデルとして図 3 に示す半径 $r_{\mathrm{f}}$, 長さ $20 \times r_{f}$ の円柱状繊維の表面に，厚さたのマトリックスが形成さ れている単繊維を対象とした。解析には沉用の弾性有限要素法 プログラム（四角形軸対象要素）を用い，対称性から図中の灰 色部分を要素分割し，解析を行った。繊維の軸方向に一様引張 応力を負荷し、マトリックスに生じたき裂が応力軸に直角方向 に, 外表面から繊維に向かって進展する場合について解析を 行った ${ }^{13), 14)}$

また, 応力扗大係数解析は有限要素法により得られたき裂先 端近傍の開口変位の結果を, 応力拡大係数が既知の基準問題に 


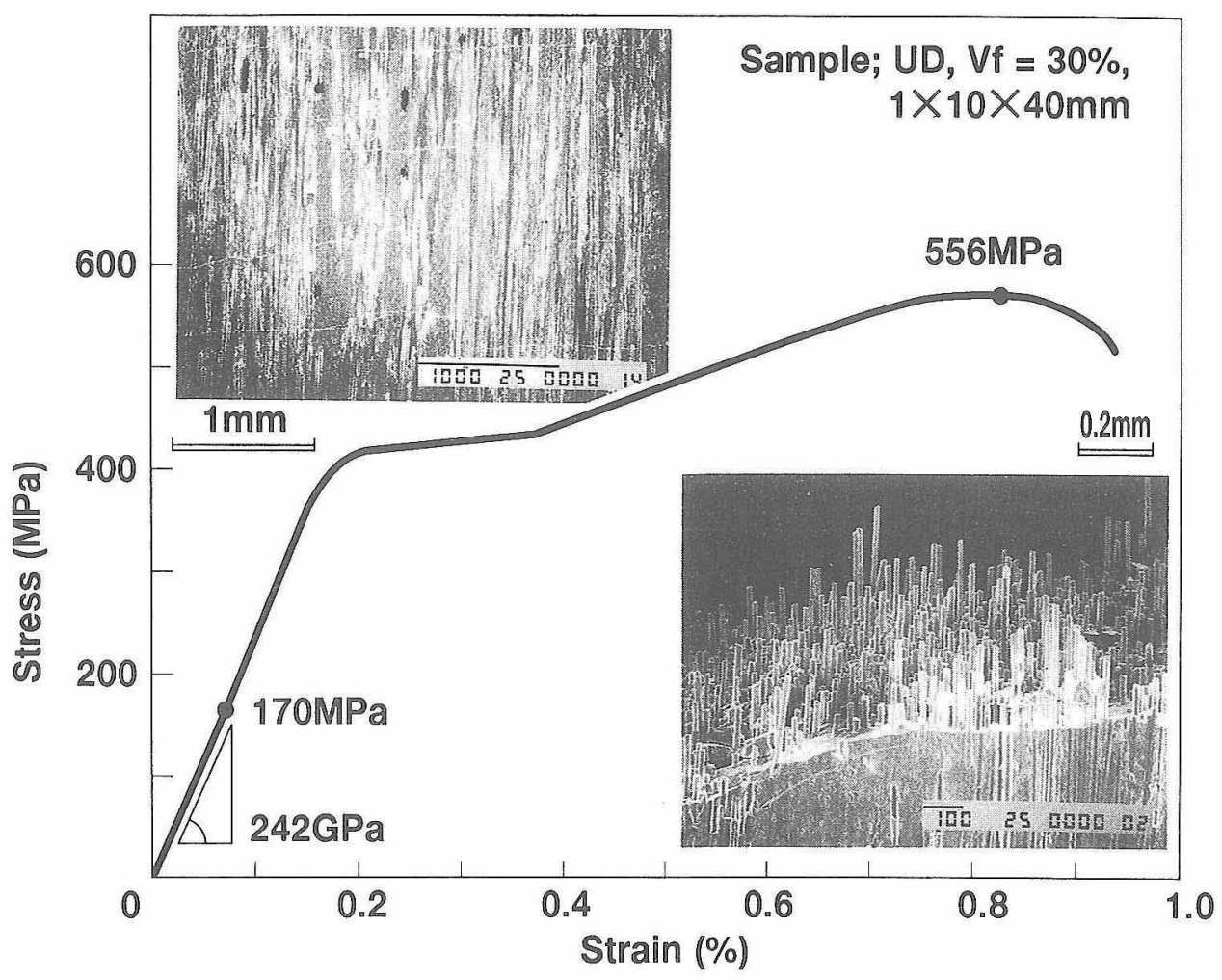

Fig. 1. Stress-strain curve of $\mathrm{SiC}_{\mathfrak{f}} / \mathrm{SiC}$ composite due to uniform tension.

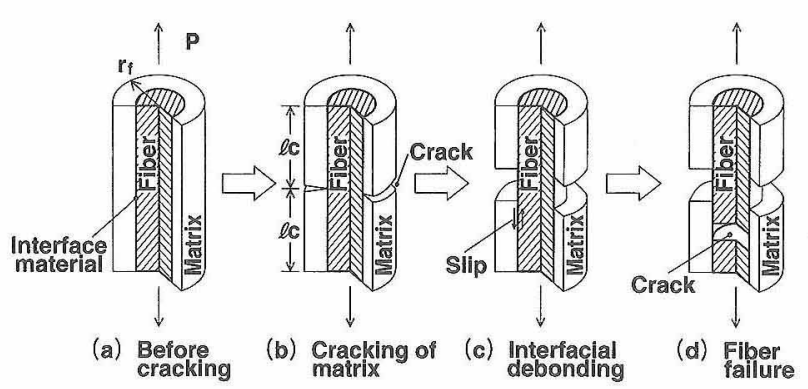

Fig. 2. Schematic failure mode of ceramic matrix composite.

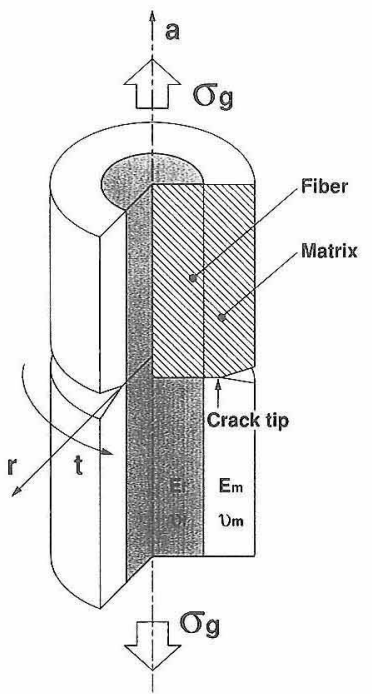

Fig. 3. Analysis model of finite element method for matrix cracking.
より補正を行う比例外挿法 ${ }^{14)}$ を用いた，有限要素法解析は緎 維半径を $r_{\mathrm{f}}=7 \mu \mathrm{m}$ とし，マトリックスの厚さを $t=4.2,5.6$, $8.75 \mu \mathrm{m}$ と変えることにより行った，これは次式により算定さ れる㵶維含有率が $V_{\mathrm{f}}=20,30,40 \%$ に対応する。

$$
V_{\mathrm{f}}=r_{\mathrm{f}}^{2} /\left(r_{\mathrm{f}}+t\right)^{2}
$$

また, マトリックスと瀻維のヤング率の比が $E_{\mathrm{m}} / E_{\mathrm{f}}=0.5$, $0.75,1.0,1.5,2.00$ 場合について解析を実施した。ただし，ポ アソソ比はマトリックス, 繊維とむに $v_{\mathrm{m}}=v_{\mathrm{f}}=0.25$ とした. き 裂先端近傍の応力值を用いた比例外插法でも応力拡大係数を算 定したが，き裂先端近傍の開口変位を用いた場合の結果と最大 4\%の䛊差の範囲内で一致することが砟認できた.

\section{3. 有限要素法解析結果}

\section{1 マトリックスき裂近傍の応力分布}

図 4 には，緎維含有率が $V_{\mathrm{f}}=30 \%$ の場合に扣いて，マト リックス厚さの $60 \%$ の深さまで外周円環状き裂が生じたとき のき裂近傍の応力分布をまとめて示す。また，図 4 は，図3 に示寸斜線領域の引張軸方向応力 $\sigma_{\mathrm{a}}$, 半径方向応力 $\sigma_{\mathrm{r}}$, 円周 方向応力 $\sigma_{t}$, せ九断応力 $\tau_{\mathrm{ra}}$ の各応力成分の分布㘠であり，き 裂先端を図中に矢印で示す，各図はマトリックスと繊維のヤン グ率の比が (a) $E_{\mathrm{m}} / E_{\mathrm{f}}=0.75$, (b) $E_{\mathrm{m}} / E_{\mathrm{f}}=1.0$, (c) $E_{\mathrm{m}} / E_{\mathrm{f}}=1.5$ の 結果でめり，各応力成分は一様引張応力 $\sigma_{g}$ で無次元化した值 を示す、いずれの結果からも，き裂先端に高い応力集中の生じ ることが分かる。ママトリックスと繊維のヤング率が同じ $\left(E_{\mathrm{m}} /\right.$ $\left.E_{\mathrm{f}}=1.0\right)$ 場合上比較すると, $E_{\mathrm{m}} / E_{\mathrm{f}}=0.75,1.5$ い゙れの場合 も, 引張軸方向応力 $\sigma_{\mathrm{a}}$, 円周方向応力 $\sigma_{\mathrm{t}}$ に関しては, マト リックスと瀻維の界面で不連続分布上なることが分かる。特 に，初期欠宿からのき裂発生特性に大きな影響を及ぼす $\sigma_{\mathrm{a}}$ 応 力成分に注目すると，強化繊維に比べてマトリックスのヤング 率が低い場合 $\left(E_{\mathrm{m}} / E_{\mathrm{f}}=0.75\right)$ には，き裂先端近傍の応力值は 低くなる傾向を示すことが分かる，一方，繊維に比べてマト 


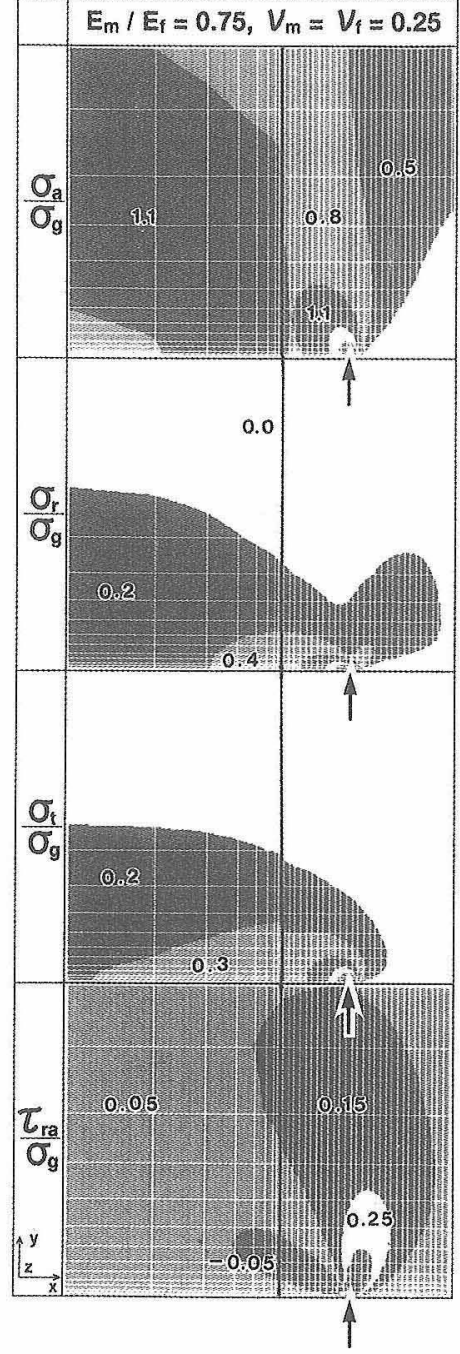

(a)

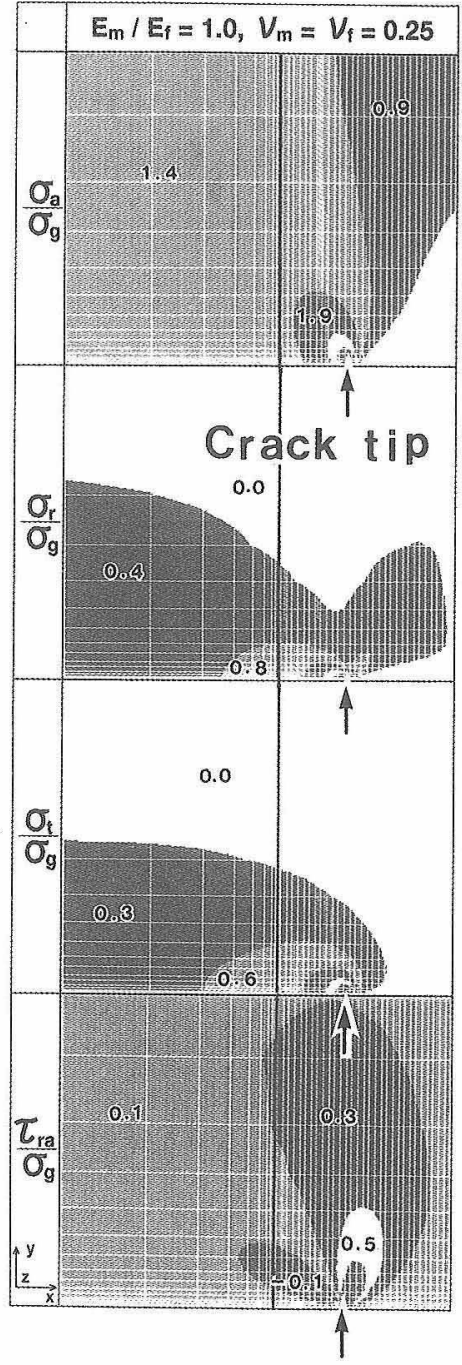

(b)

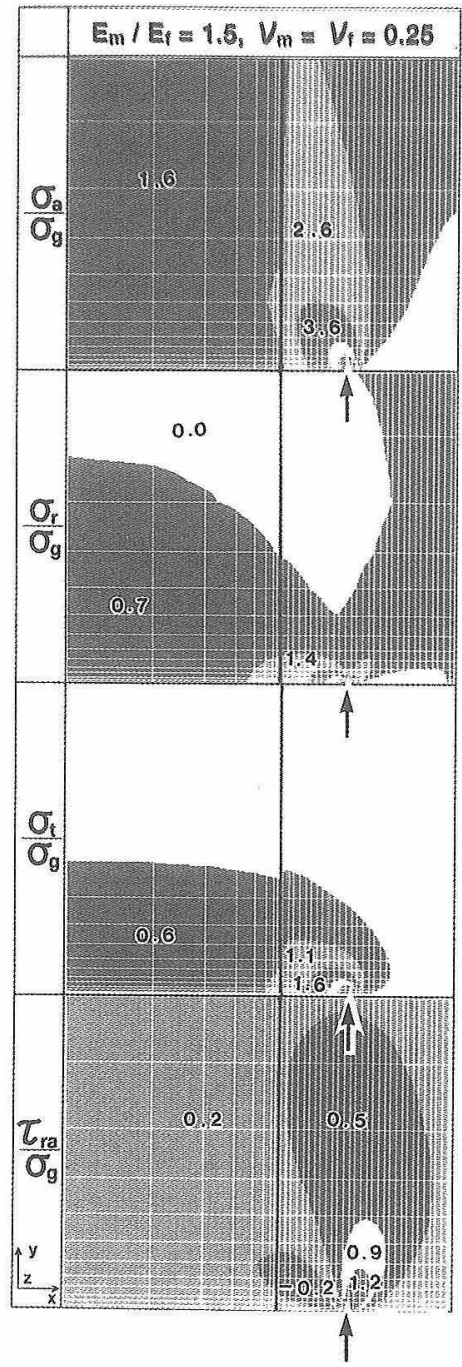

(c)

Fig. 4. Effect of Young's modulus ratio on stress distribution near crack-tip.

(a) Young's modulus ratio: $E_{\mathrm{m}} / E_{\mathrm{f}}=0.75$,

(b) Young's modulus ratio: $E_{\mathrm{m}} / E_{\mathrm{f}}=1.0$

(c) Young's modulus ratio: $E_{\mathrm{m}} / E_{\mathrm{f}}=1.5$.

リックスのヤング率が高い場合 $\left(E_{\mathrm{m}} / E_{\mathrm{f}}=1.5\right)$ には，き裂先 端近傍の応力値は高くなる傾向を示す，同様の傾向は，そのほ かの応力成分に招いても認められる，同じ一様引張応力が作用 する場合には，䄉維に比べてヤング率が高いマトリックスを選 択すると，マトリックス中の初期欠陷からのき裂の発生は生じ やすく、マトリックス強度が見掛忖上低くなることが分かる。

\section{2 マトリックス中き裂の応力拡大係数}

マトリックス中の初期欠宿からのき裂発生特性を明らかにす るためには，応力拡大係数を求めて破壊力学的検討を加える必 要がある. 本問題の応力拡大係数 $K_{\mathrm{I}}$ は, 一様引張応力 $\sigma_{\mathrm{g}}$ と き裂深さ $c$ の関数として次式で表される，ただし，F $F_{\mathrm{I}}$ は形状 々材料の機械的性質の関数である.

$$
K_{\mathrm{I}}=\sigma_{\mathrm{g}} \cdot \sqrt{\pi c} \cdot F_{\mathrm{I}}\left\{E_{\mathrm{m}} / E_{\mathrm{f}}, r_{\mathrm{f}} / t, c / t \cdots\right\}
$$

图 5 (a)，(b)，(c)には，それぞれ $V_{f}=20,30,40 \%$ の場合に ついて， $K_{\mathrm{I}} / \sigma_{g}$ 値を計算した結果をすとめて示す，ただし，横 軸には緇維中心を原点としたき裂先端の位置を示す．き裂先端 位置がマトリックス/瀻維界面に近づくと，き裂が深くなり， 応力桩大係数は急激に高くなる傾向を示生中图中に示卞 $E_{\mathrm{m}} / E_{\mathrm{f}}$
$=1.0$ 結果は，円周き裂を有ずる中央丸棒均質材の応力拡大 係数と一致する。この結果と比較すると，瀻維に比べてマト リックスのヤング率が低い場合 $\left(E_{\mathrm{m}} / E_{\mathrm{f}}<1.0\right)$ には，応力桩 大係数は低くなる傾向が認められる，また，この傾向はき裂が 深いはど顕著となることが明らかである。このことは䋐維に比 ベてマトリックスのヤング率が低い場合には，マトリックスに 許容される初期欠陥寸法は大きくなることを意味しており，マ トリックスのき裂発生強度が高くなる可能性を示している。逆 に，瀻維に比ベてマトリックスのヤング率が高い場合 $\left(E_{\mathrm{m}} / E_{\mathrm{f}}\right.$ $>1.0$ ）には，応力拡大係数は均質材の場合上り。高くなる傾 向が認められる，なた，この傾向はき裂が深い㤬じ顕著となる ことが明らかである。このようなき裂深さが応力桩大係数に及 ぼす影響は, 繊維含有率が变わっても基本的には同じ傾向を示 す.一方, 異種材料接合界面では, 低ヤング率材料に生じたき 裂が高ヤング率材料に向けて進展する場合，接合界面近傍で応 力桩大係数の上昇鈍化，あるいは逆に低下する傾向を示吉場合 のあることが知られている13)。しかし，本解析の範囲内では 接合界面の影響よりも，き裂深さが応力拡大保数に及ぼす影響 


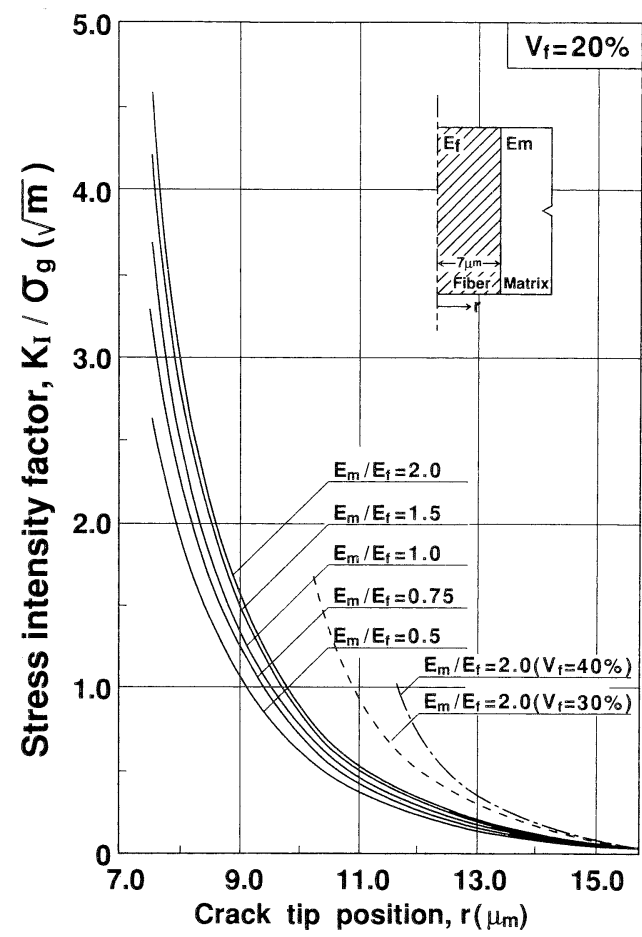

(a)

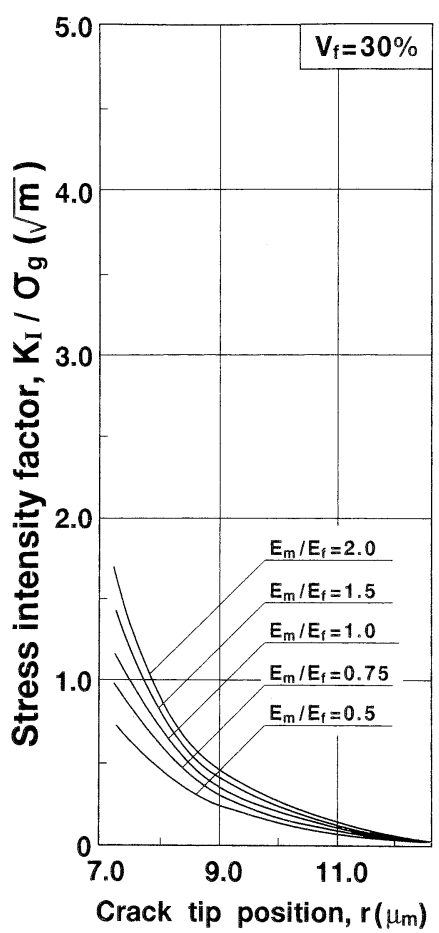

(b)

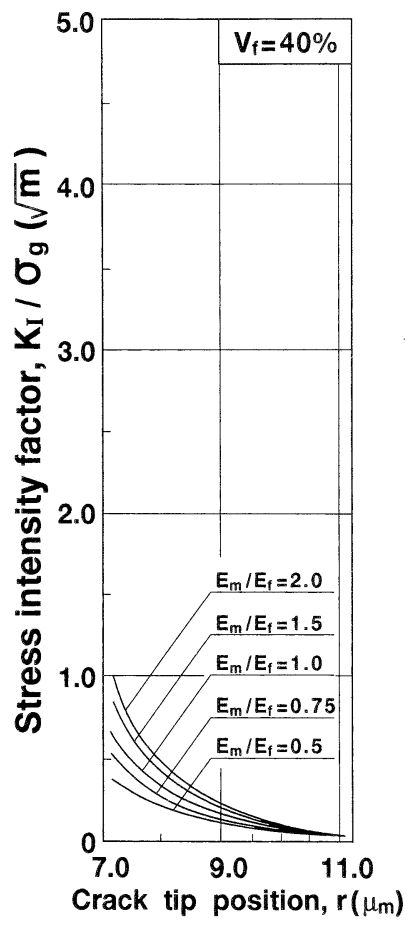

(c)

Fig. 5. Effect of Young's modulus ratio on stress intensity factor for matrix cracking: (a) fiber volume fraction: $V_{\mathrm{f}}=20 \%$, (b) fiber volume fraction: $V_{\mathrm{f}}=30 \%$, (c) fiber volume fraction: $V_{\mathrm{f}}=40 \%$.

が顕著であり，き裂深さとともに連続的に応力拡大係数が上昇 する傾向を示した。

繊維含有率が応力拡大係数に及ぼす影響は, 図 5(a), (b), (c) を比較することにより明らかである。特に，図 5(a)には $E_{\mathrm{m}} / E_{\mathrm{f}}=2.00$ 場合について緎維含有率の影響 $V_{\mathrm{f}}=20,30,40 \%$ の結果を比較して示す, 同じき裂深さで比較すると, き裂深さ が強化繊維間の距離に対して十分に小さい場合には, 繊維含有 率が応力扗大係数に及ぼす影響は顕著ではない。しかし，き裂 深さが強化絨維間の距離に対して無視できない大きさの場合に は, 繊維含有率の高いほと， 応力桩大係数は高い值を示す。こ れは比較的大きな初期欠陷が強化繊維の中間に存在する場合, 繊維含有率の高いほど, マトリックスのき裂発生強度が低くな る可能性を示している, むた，䋐維含有率が低くなるほどマト リックス/繊維界面近傍では応力桩大係数は顕著に高い值を示 す傾向が認められる。これから，瀻維含有率が低いほど発生し たき裂は大きく進展し、マトリックス/繊維界面に向けてき裂 進展が加速される傾向にあることが分かる。き裂進展の加速傾 向が強い場合には, マトリックスに生じたき裂は界面を通過し て直接強化絨維に進展し, 繊維の引き抜け効果を発現しない可 能性が生じる。

\section{3 マトリックス/繊維界面はく離応力}

図 2 で示すようにマトリックスに発生したき裂が進展しマ トリックス/繊維界面に到達した時点で，き裂が界面に沿って 進展することは，セラミック基複合材料に抢ける勒性発現のた めには重要な現象である。すなわち、マトリックスに発生した き㱟が直接強化䋐維中に進展しないためには, マトリックス/ 繊維界面のはく離が必須条件となる。この界面はく離の条件に ついては, マトリックスに発生したき裂の先端が界面に近づい てきたときの応力分布特性, すなわち半径方向応力 $\sigma_{\mathrm{r}}$, せん 断応力 $\tau_{\mathrm{ra}}$ の応力分布特性が大きな影響を及ぼすと考えられ
る10) 12)，特に，き裂が界面に到達する以前に引張応力 $\sigma_{\mathrm{r}}$ に より界面はく離を生じる場合が，Cook-Gordonの機構10) と呼 ばれ，よく報告されている.

図 6 と図 7 には，それぞれマトリックス/繊維界面に抢ける $\sigma_{\mathrm{r}}, \tau_{\mathrm{ra}}$ 応力成分の最大値に及ぼす, 繊維とマトリックスのヤン グ率比 $\left(0.5 \leqq E_{\mathrm{m}} / E_{\mathrm{f}} \leqq 2.0\right)$ ，ならびにマトリックス中のき裂先 端位置の影響をなとめて示す。ただ，代表例として緎維含有 率 $V_{\mathrm{f}}=30 \%$ の場合の解析結果を示す. 図 6 中に示すように界 面に打ける $\sigma_{\mathrm{r}}$ 応力分布は，き裂の延長線上に㧤いて最大值を 示した．この $\sigma_{\mathrm{r}}$ 值はき裂先端位置が界面に近づくほど急激に 高くなる傾向を示す。また，マトリックスと瀻維のヤング率が 同じ $\left(E_{\mathrm{m}} / E_{\mathrm{f}}=1.0\right)$ 場合と比較すると, 繊維に比べてマト リックスのヤング率が低い場合 $\left(E_{\mathrm{m}} / E_{\mathrm{f}}<1.0\right)$ には， $\sigma_{\mathrm{r}}$ 值は 低くなる傾向を示す。逆に, 繊維に比べてマトリックスのヤン グ率が高い場合 $\left(E_{\mathrm{m}} / E_{\mathrm{f}}>1.0\right)$ には， $\sigma_{\mathrm{r}}$ 值は高くなる傾向を 示し, 繊維/マトリックス界面のはく離が生じやすい上考えら れる。

一方, 図 7 中に示すように繊維/マトリックス界面に抢ける $\tau_{\mathrm{ra}}$ は, き裂先端から上下に $30 \sim 45^{\circ}$ の延長線上の界面で最大值 を示す。この $\tau_{\mathrm{ra}}$ 值についてもき裂先端位置が界面に近づくほ ど急激に高くなる傾向を示す。 また, マトリックスと䋐維のヤ ング率が同じ $\left(E_{\mathrm{m}} / E_{\mathrm{f}}=1.0\right)$ 場合と比較すると, 䋐維に比べ てマトリックスのヤング率が低い場合 $\left(E_{\mathrm{m}} / E_{\mathrm{f}}<1.0\right)$ には $\tau_{\mathrm{ra}}$ 值は低くなる傾向を示す，逆に，纎維に比べてマトリックスの ヤング率が高い場合 $\left(E_{\mathrm{m}} / E_{\mathrm{f}}>1.0\right)$ には $\tau_{\mathrm{ra}}$ 值は高くなる傾向 を示す。 また， $\tau_{\mathrm{ra}}$ 值と比較すると図 6 の $\sigma_{\mathrm{r}}$ 值は全体に $4 \sim 7$ 倍程度高めの值を示し，き裂先端位置が界面から離れている場 合でも $\sigma_{\mathrm{r}}$ 值の方が高い值を示す傾向が見られる、マトリック ス/繊維界面の密着強度特性にも依存するが，応力值の高さを 比較すると界面はく離は主に $\sigma_{\mathrm{r}}$ 応力成分によって規定される 


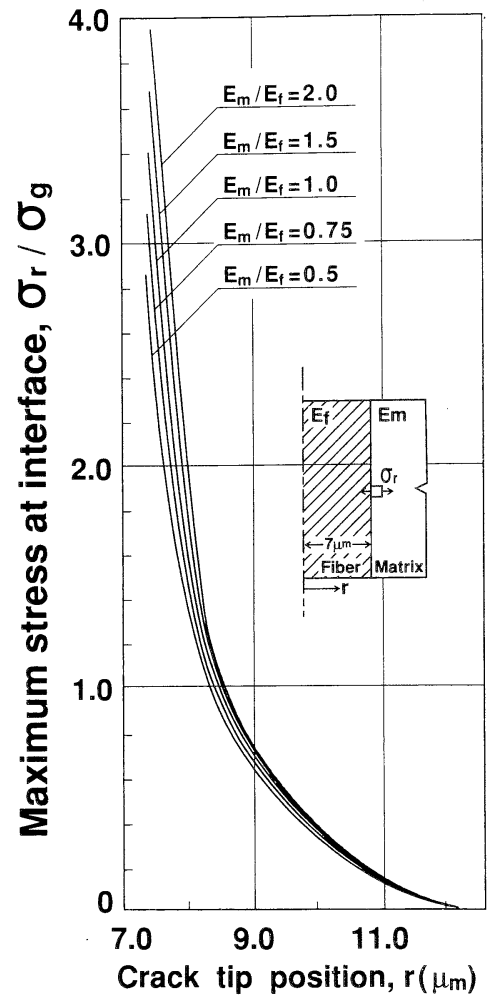

Fig. 6. Effect of Young's modulus ratio on maximum $\sigma_{\mathrm{r}}$ stress at interface.

\section{と考えられる}

\section{4.マトリックスと繊維の適合性に関する考察}

線形破壊力学解析により, マトリックスの初期欠陥からのき 裂発生特性は, マトリックスと繊維のヤング率比 $\left(E_{\mathrm{m}} / E_{\mathrm{f}}\right)$ と，繊維含有率によって大きな影響を受けることが示された。 特に，繊維に比べてマトリックスのヤング率が低い場合には， マトリックスに許容される初期欠陥寸法は大きくなり, マト リックスのき裂発生強度が高くなる可能性のあることが明らか となった。

一方，マトリックスのき裂発生特性には，マトリックスに作 用する残留応力も大きな影響を及ぼすと考えられる。強化繊維 に比べて熱膨張係数の低いマトリックスを選択すると，セラ ミック基複合材料の創製プロセスにより，マトリックスに緎維 方向の压縮残留応力を誘起させることが可能である11)。マト リックスに圧縮残留応力が誘起さ机ると，マトリックスのき裂 発生を抑制することが可能となる。そこで，マトリックスの初 期欠陥からのき裂発生特性を考察するにあたり, マトリックス と繊維のヤング率, 熱膨張係数の関係を明確にすることが重要 である。

図 8 には各種セラミック基複合材料に用いられているマト リックスと強化繊維について，ヤング率と熱膨張係数の関係を プロットする6),15) 17)。ただし，ヤング率は室温 $298 \mathrm{~K}$, 熱膨 張係数は $400 \sim 1200 \mathrm{~K}$ の值である. 以下では，このマップを 用いてマトリックスの初期欠陷からのき裂発生特性から見た， マトリックスと強化瀻維の適合性について考察を加える。一例 として，ハイ二カロン繊維（Hi-Nicalon，日本カーボン製）を 強化繊維として選択した場合, マトリックス材料が 4 領域に 分類できることを図 8 中に示す。領域 III, IV は繊維に比べて マトリックスのヤング率が低い場合で，マトリックスに許容さ

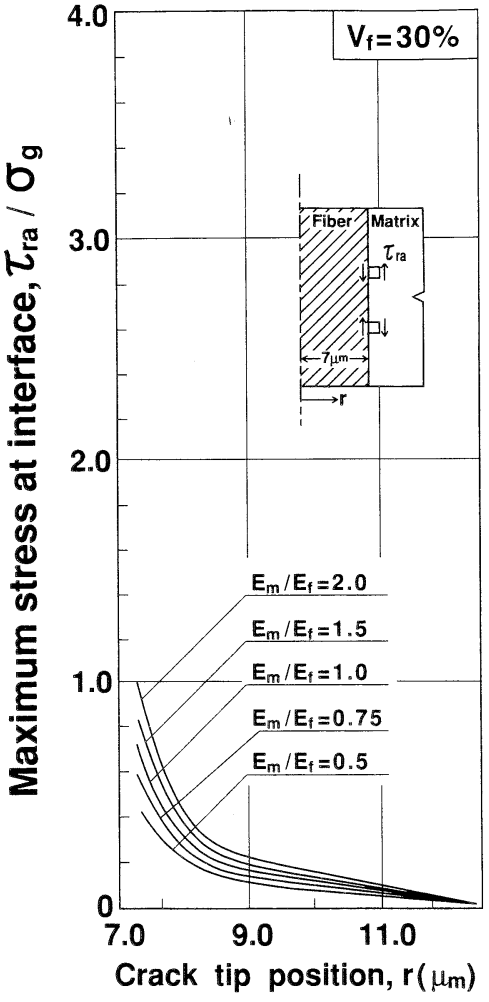

Fig. 7. Effect of Young's modulus ratio on maximum $\tau_{\text {ra }}$ stress at interface.

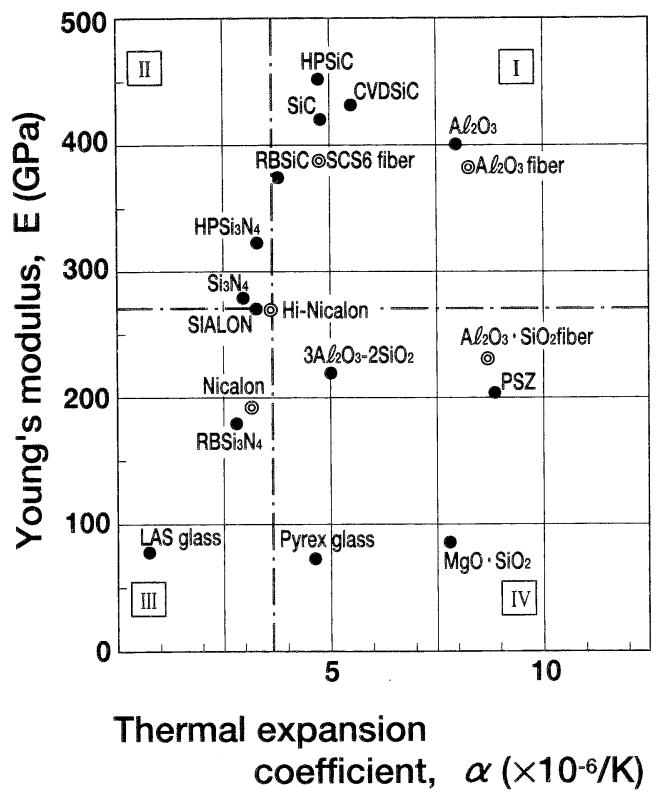

Fig. 8. Relationship between Young's modulus and thermal expansion coefficient for various fiber and matrix materials.

れる初期欠陷寸法は大きくなり, マトリックスのき裂発生強度 が高くなる領域である。このような観点からは, ハイニカロン 繊維との適合性を考慮すると反応焼結窒化ケイ素 $\left(\mathrm{RB}^{-} \mathrm{Si}_{3} \mathrm{~N}_{4}\right)$ やガラスがマトリックスとして優れていることが分かる。一 方，八イ二カロン繊維に比べて熱膨張係数の低いマトリックス は領域 II, III に位置する材料であり，マトリックスに王縮残 留応力が誘起できる材料として各種窒化ケイ素, リチウムアル 
ミノケイ酸塩 (LAS) ガラスなどの選択が有効である.以上 の結果から, ハイ二カロン繊維に比べてヤング率, 熱膨張係数 ともに低いマトリックスは領域 III に位置する材料であり，マ トリックス破壊強度を高くできる材料として, 反応焼結空化ケ イ素やLAS ガラスが有効であることが分かる。

以上に示したマトリックスのき裂発生応力と, マトリック ス/繊維界面のはく離応力の状態を, 残留応力と負荷応力につ いて分かりやすく図示したものが図9である。たたし、マト リックス/繊維界面が直接結合した場合を対象としたものであ る。縦軸はマトリックスと䋐維のヤング率比, 横軸はマトリッ クスと瀻維の熱膨張係数差である. 領域 Iのマトリックス材料 には引張残留応力と高い負荷応力が作用しマトリックスのき裂 発生強度は低下する。 屯た, マトリックス/繊維界面には圧縮 残留応力上高いはく離応力が作用し, 両者のバランスで強化緎 維の引き技け特性が決定される。領域 II のマトリックス材料 には王縮残留応力と高い負荷応力が作用し, 雨者のバランスで マトリックスのき裂発生強度が決定される。マトリックス/繊 維界面には引張残留応力上高いはく離応力が作用し, 強化繊維 の引き抜けは容易に生じると考えられる。領域 III のマトリッ クス材料には王縮残留応力と低い負荷応力が作用し, 両者のバ ランスでマトリックスき裂発生強度は決定される。 マトリック ス/繊維界面には引張残留応力上低いはく離応力が作用し, 強 化繊維の引き抜けも比較的容易に生じると考えられる. 領域 IVのマトリックス材料には引張残留応力と低い負荷応力が作 用し, マトリックス強度はやや低目となる。なた, マトリック 又/繊維界面には压縮残留応力と低いはく離応力が作用し, 両 者のバランスで強化繊維の引き抜け特性が決定される。すなわ ち, マトリックスき裂発生強度を高く設計するためには, 領域 III に位置するマトリックス材料の選択が有効なことを前述し たが，セラミック基複合材料において重要な繊維の引き抜け効 果をあわせて考慮すると, 領域 II のマトリックス材料も有効

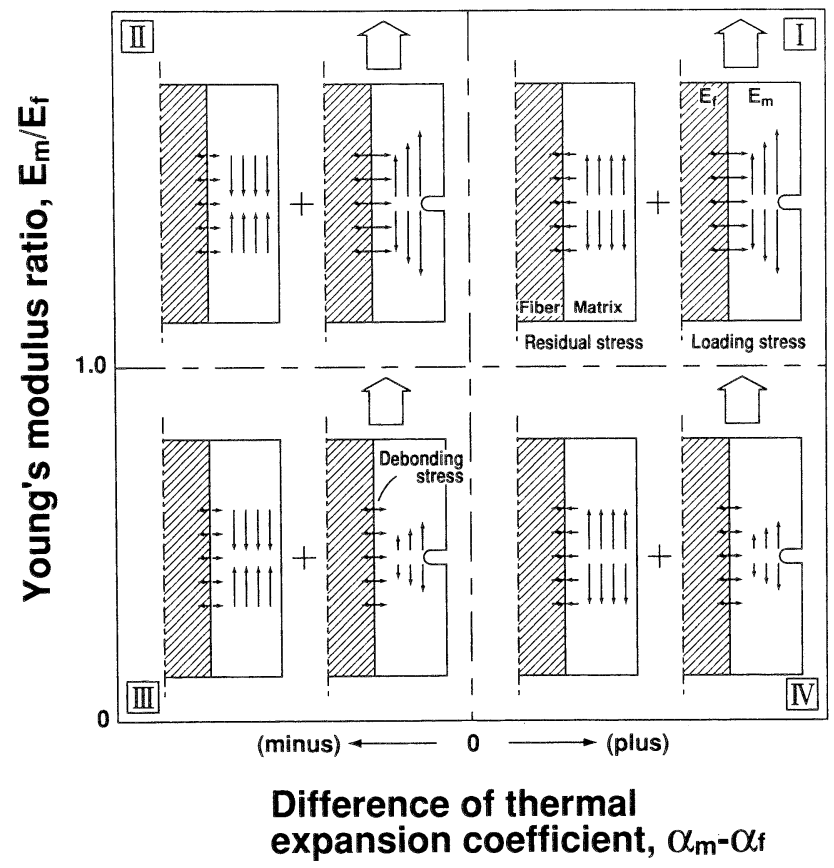

Fig. 9. Effect of Young's modulus ratio and difference of thermal expansion coefficient on crack growth and debonding.
と考えられる.

\section{5. 結 論}

（1）線形破壊力学解析により，マトリックスの初期欠陥か らのき裂発生特性は, マトリックスと繊維のヤング率比と, 繊 維含有率によって大きな影響を受ける。特に，ヤング率比が低 い $\left(E_{\mathrm{m}} / E_{\mathrm{f}}<1.0\right)$ ほど応力拡大保数は低くなる傾向を示し， マトリックスき裂発生強度を高くするために有効と考えられ る.

（2）同一き裂深さでは，き裂深さが䋐維間距離に対して十 分小さい場合, 繊維含有率が応力拡大係数に及ぼす影響は顕著 ではない。しかし，き裂深さが繊維間距離に対して無視できな い場合, 繊維含有率の高いほど応力拡大係数は高い值を示し, マトリックスき裂発生強度を低下させる。

（3）マトリックス/繊維界面に招ける $\sigma_{\mathrm{r}}, \tau_{\mathrm{ra}}$ 応力成分は, き裂先端位置が界面に近づくほど, ヤング率比が高い場合 $\left(E_{\mathrm{m}} / E_{\mathrm{f}}>1.0\right)$ ほ ぼ高くなる傾向を示し，マトリックス/繊維 界面のはく離を生じやすくするためには，ヤング率比が高い材 料の組み合わせが有効である。

（4）マトリックスのき裂発生抑制の観点からは，強化繊維 よりもヤング率の低いマトリックスの選択，マトリックスに圧 縮残留応力を導入するため繊維よりも熱膨張係数の低いマト リックスの選択が有効であり，このような材料選択のための マップを作成し考察を加えた。

（5）マトリックスのき裂発生を抑制するとともに，䋐維の 引き抜け効果を十分に発揮させる観点から, 繊維に比べてヤン グ率の高いマトリックスの選択と, マトリックスに王縮残留応 力を導入するため緎維に比べて熱膨張係数の低いマトリックス を選択することが有効である。

\section{文献}

1) G. S. Corman, J. T. Heinen and R. H. Goetze, ASME Paper, 95-GT-387 (1995).

2) M. H. Van de Voorde and M. R. Nedele, Ceram. Eng. Sci. Proc., 17-4, Am. Ceram. Soc., Westerville, OH (1996) pp. 320.

3) J. Garnier, M. Headinger, K. Ueda and K. Hatton, Int. Gas Turbine Congr., Yokohama (1995) pp. I73-80.

4) 岡村清人, 日本複合材料学会誌, 20, 34-41 (1994).

5）香川 豊, セラミックス, 31, 656-61 (1996).

6）伊藤義康, 亀田常治, 西田勝利, 梅澤正信, 今井義一, 市川 宏, J. Ceram. Soc. Japan, 106, 830-34 (1998).

7) T. Kameda, S. Suyama, Y. Hayakawa, N. Amiji, M. Umezawa and H. Ichikawa, Proc. 4th Japan Int. SAMPE Symposium (1995) pp. 252-57.

8）伊藤義康, 亀田常治, 池田 功, 須山章子, 日本材料学会高 温強度部門委員会講演会資料, 46-3 (1997) pp. 1-7.

9）長村光造，落合庄治郎，酒井 明，材料， 43, 1065-75 (1994).

10) J. Cook and J. E. Gordon, Proc. Roy. Soc. Lond., A299 (1967) pp. 508-13.

11) K. Goto and Y. Kagawa, Mater. Sci. Eng., A176, 357-61 (1994).

12) Y. Kagawa and K. Goto, “Ceramic Transaction," Vol. 57, Am. Ceram. Soc. (1995) pp. 247-51.

13）伊藤義康, 斉藤正弘, 宮崎松生, 日本機械学会論文集, A60-579, 2538-43 (1994).

14) Y. Itoh, Nucl. Eng. Des., 94, 249-55 (1986).

15）香川 豊, 八田博志, “セラミック基複合材料”, アグネ承風 社 (1990) pp. 12-39.

16）奥田 博, 平井敏雄, 上垣外修己, “構造材料セラミクス”, オーム社 (1987) pp. 9-55.

17）市川宏, 放射線化学, 58, 21-29 (1994). 